\title{
Protein and Fiber Profiles of Cottonseed from Upland Cotton with Different Fertilizations
}

\author{
Zhongqi He ${ }^{1}$, Hailin Zhang ${ }^{2}$, Daniel C. Olk ${ }^{3}$, Mark Shankle ${ }^{4}$, Thomas R. Way ${ }^{5} \&$ Haile Tewolde ${ }^{6}$ \\ ${ }^{1}$ USDA-ARS, Southern Regional Research Center, 1100 Robert E Lee Blvd., New Orleans, LA 70124, USA \\ ${ }^{2}$ Dept. of Plant and Soil Sciences, Oklahoma State University, Stillwater, OK 74078, USA \\ ${ }^{3}$ USDA-ARS, National Laboratory for Agriculture and the Environment, Ames, IA 50011, USA \\ ${ }^{4}$ Pontotoc Ridge-Flatwoods Branch Experiment Station, Mississippi State Univ., Pontotoc, MS 38863, USA \\ ${ }^{5}$ USDA-ARS, National Soil Dynamics Laboratory, Auburn, AL 36832, USA \\ ${ }^{6}$ USDA-ARS, Crop Science Research Laboratory, Mississippi State, MS 39762, USA \\ Correspondence: Zhongqi He, USDA-ARS, Southern Regional Research Center, 1100 Robert E. Lee Blvd., New \\ Orleans, LA 70124, USA. Tel: 1-504-286-4516. Fax: 1-504-286-4367. E-mail: Zhongqi.He@ars.usda.gov
}

\author{
Received: April 21, 2014 Accepted: May 5, $2014 \quad$ Online Published: June 25, 2014 \\ doi:10.5539/mas.v8n4p97 URL: http://dx.doi.org/10.5539/mas.v8n4p97
}

\begin{abstract}
Whole cottonseed and its derived products can be used as human food, animal feed, and industrial raw material. Chemical composition of cottonseed is one of the critical parameters for evaluating its quality and potential end use. Especially, protein and dietary fibers are two desirable nutritional properties of cottonseed for animal feed. In this study, we determined their contents in cottonseed harvested from different fertilization managements with or without wheat cover crop in two consecutive years. Seed content of crude protein increased in the order of no fertilizer $\leq$ poultry litter $\leq$ chemical fertilizer. Both neutral and acid detergent fiber profiles were affected by fertilization and planting year/cover crop in an order reversing that of crude protein. Few statistically significant $(P>0.05)$ impacts were observed on the content of acid detergent lignin. Observations derived from this work will provide information on nutritional value and digestibility of cottonseed as affected by cropping management practices.
\end{abstract}

Keywords: cottonseed, poultry litter, amino acid, neutral detergent fiber, acid detergent fiber

\section{Introduction}

Cotton (Gossypium hirsutum L.) is a major crop in the world (Bellaloui and Turley, 2013). For every $100 \mathrm{~kg}$ of lint fiber ginned from cotton, $150 \mathrm{~kg}$ of cottonseed is produced (Yu et al., 2012). Thus, cottonseed is an abundant resource for oil, meal and protein for human consumption, animal feed, and industrial raw material (Coppock et al., 1987; Gao et al., 2010; He et al., 2013a; 2014a; 2014b; Kandasamy et al., 2008; Zhang et al., 2009). The chemical composition is an important parameter in evaluating cottonseed quality for these different applications. In a previous research (He et al., 2013b), we collected the cottonseed samples in two successive years from cotton grown in a Falkner silt loam soil in northeastern Mississippi, USA. The cotton crop was fertilized with poultry litter (PL) and chemical inorganic fertilizer (CIF) with or without wheat cover crop. We determined the ash and elemental contents of these samples. Whereas cover crop did not significantly impact the elemental composition of cottonseed, fertilization decreased $\mathrm{Ca}$, but increased $\mathrm{Fe}$ and $\mathrm{Mn}$ contents. The CIF treatment decreased but $\mathrm{PL}$ fertilization increased $\mathrm{P}, \mathrm{Mg}, \mathrm{Cu}$, and ash contents. Regression analysis suggested that $\mathrm{P}, \mathrm{Mg}$, and $\mathrm{K}$ contributed to the increase of ash content, probably in the form of the mixture of $\mathrm{K} / \mathrm{Mg}$ phytate compounds.

Crude protein and dietary fiber profiles of cottonseed are important parameters in evaluating the nutrient content of cottonseed (Coppock et al., 1987; Myer, 2012). Amino acids in feedstuff are divided into essential amino acids and nonessential amino acids (Edmunds et al., 2013). The nutrient value of cottonseed protein might be dependent not only on the total protein content, but also on the level of essential amino acids (Bertrand et al., 2005). Neutral detergent fiber (NDF) is related to feed intake and acid detergent fiber (ADF) estimates feed digestibility, so both ADF and NDF are useful measures of relative feed value, and are frequently used to 
evaluate forage quality and formulate rations (Rasby et al., 2008). Lignin or acid detergent lignin (ADL) is another parameter as it represents the highly indigestible portion associated with fiber. Therefore, to complement the earlier work of the ash and elemental contents of cottonseed (He et al., 2013b), we analyzed the protein, amino acid, and fiber contents in the cottonseeds sampled in two years under different fertilization management sin this study. Results presented in this study amplify the database and knowledge of protein and dietary fiber profiles of cottonseed impacted by agronomic management practices, which currently are rarely available (Bellaloui \& Turley, 2013; Bertrand et al., 2005).

\section{Materials and Methods}

\subsection{Field Study and Seed Sample Preparation}

The field experiment was conducted in 2009 and 2010 at the Mississippi Agricultural and Forest Experiment Station near Pontotoc, MS on a Falkner silt loam soil (Fine-silty, siliceous, active, thermic Aquic Paleudalfs). Initially, the soil had pH 6.2 (1:1 soil: water), $0.82 \mathrm{~g} \mathrm{~kg}^{-1}$ total $\mathrm{N}$, and $9.5 \mathrm{~g} \mathrm{~kg}^{-1}$ total C. Details of the experiment were reported previously (He et al., 2013b). Briefly, the experiment (Table 1) consisted of PL application methods of subsurface band vs. surface broadcast both at $5.6 \mathrm{Mg} \mathrm{ha}^{-1}$, application timing of fall vs. spring, and with vs. without winter wheat cover crop. These factors were compared against a standard commercial fertilization (CIF) and an unfertilized control (Con). Winter cover crop was applied to the main plots and a factorial combination of the application method and timing to subplots. Each subplot consisted of four rows ( $1.02 \mathrm{~m}$ row spacing) with 21.3 -m length. The field was managed as a no-till system.

For each subplot, about $1.0 \mathrm{~kg}$ subsample was taken from the cotton harvested each year, ginned on a 10 -saw tabletop gin, and the cottonseed delinted with concentrated $\mathrm{H}_{2} \mathrm{SO}_{4}$, rinsed with tap water, and dried in a forced-air oven at $65^{\circ} \mathrm{C}$. Approximately $120 \mathrm{~g}$ dried seeds from each sample were then ground in a stainless steel coffee grinder and sieved to pass a $0.5 \mathrm{~mm}$ stainless steel sieve (\#35 US Standard Test Sieve). Part of the sample that did not pass through this sieve was further ground in the coffee grinder and sieved again. The portion of each sample that still did not pass this sieve was ground in a stainless steel Wiley Mill to pass a $1 \mathrm{~mm}$ screen (\#20) and thoroughly blended with the remainder of the sieved sample. The portion that was ground by the Wiley Mill was mostly hull pieces and was only a small fraction of the total.

Table 1. Description of the fertilization treatments and the timing and method of their application. The cover crop or no cover crop treatments were superimposed over these treatment combinations

\begin{tabular}{llll}
\hline Treatment & Fertilizer & Application method & Application time \\
\hline Con & Unfertilized control & - & - \\
CIF & Chemical inorganic fertilizer & Sidedress & Spring \\
LBF & Poultry litter & Broadcast & Fall \\
LBS & Poultry litter & Broadcast & Spring \\
LSF & Poultry litter & Subsurface band & Fall \\
LSS & Poultry litter & Subsurface band & Spring \\
\hline
\end{tabular}

\subsection{Carbon and Nitrogen Analysis}

The concentrations of total $\mathrm{C}$ and total $\mathrm{N}$ in each sample were determined using a LECO Truspec dry combustion Carbon/Nitrogen Analyzer (National Forage Testing Association, 1993).Crude protein content in the cottonseed samples were calculated by multiplying the total $\mathrm{N}$ by a factor of 6.25 (He et al., 2013a).

\subsection{Determination of Amino Acids}

Ion chromatography coupled with amperometric detection was used to measure 17 proteinous amino acids in the cottonseed (He et al., 2014d; Olk et al., 2008). Each sample $(20 \mathrm{mg})$ was mixed with $2 \mathrm{~mL}$ of $4 \mathrm{M}$ methanesulfonic acid (MSA)amended with $2 \mathrm{~g} \mathrm{~L}^{-1}$ tryptamine and autoclaved for $16 \mathrm{~h}$ at $136^{\circ} \mathrm{C}(112 \mathrm{kPa})$. The acid extracts were titrated to $\mathrm{pH} 4$ to 5 with $\mathrm{NaOH}$ and centrifuged to remove precipitates. The aliquots were diluted properly with purified water. Concentrations of amino acids in these diluted solutions were analyzed by a DionexDX-500 (Dionex Corp. Sunnyvale, CA) ion chromatograph equipped with an Amino-Pac PA 10 column ( $2 \mathrm{~mm}$ i.d.). Triple pulsed amperometric detection was performed using a Dionex ED-40 electrochemical detector.

\subsection{Determination of Dietary Fibers}

Acid detergent fiber, neutral detergent fiber and acid detergent lignin were determined using the filter bag 
methods with an Ankom Fiber Analyzer (Ankom Technology, Macedon, NY, 2011).

\subsection{Statistical Analysis}

The data analysis package in Microsoft Excel 2007 was used for statistical analysis. Data from field triplicates were used to calculate averages and standard deviations. "Single-factor" ANOVA was used to evaluate the effects of management treatments on AA and fiber contents of cottonseed. The Correlation Analysis Tool was used to analyze correlation coefficients between these contents.

\section{Results and Discussion}

\subsection{Crude Protein Content of Cottonseed}

The crude protein content of these cottonseed samples varied from $18.6 \%$ to $27.1 \%$ of dry matter (Figure 1 ). The protein contents of each fertilization treatment with and without cover crop in the same year were quite similar (i .e $2009-\mathrm{CC}$ vs. $2009+\mathrm{CC}$ and $2010-\mathrm{CC}$ vs. $2010+\mathrm{CC}$ ), indicating no substantial impacts of cover crop management on the protein content. The protein contents of 2010 samples were higher than the contents of the corresponding 2009 samples probably due to environmental conditions ideal for seed protein accumulation in 2010 than in 2009. Averaged across the fertilization treatments, the protein content of the no cover vs. cover crop was $20.1 \%$ vs. $19.4 \%$ of dry matter in 2009 compared with $26.0 \%$ vs. $25.8 \%$ in 2010 samples. This represents a $30 \%$ protein increase in 2010 than in 2009. Similarly, Bertrand et al. (2005) reported an 11\% difference in crude protein content between two years. In our study, the difference in protein content of the two years may be a reflection of substantially different weather conditions during the two growing seasons. While the 2009 growing season was wet and had milder air temperature, the 2010 season was much drier and hotter. Those contrasting weather conditions were reflected in the cottonseed yield: $1482 \mathrm{kgha}^{-1}$ in 2009 compared with only $976 \mathrm{~kg} \mathrm{ha}^{-1}$ in 2010. Typically, protein content in crops is inversely related to yields. In addition to the weather difference, the cultivars planted each year were different: 'DP143B2RF' in 2009 and 'DP0924B2RF' (Delta and Pine Land Company, Scott, Miss.) in 2010. Perhaps both weather and cultivar differences contributed to the difference in crude protein contents between the two years.

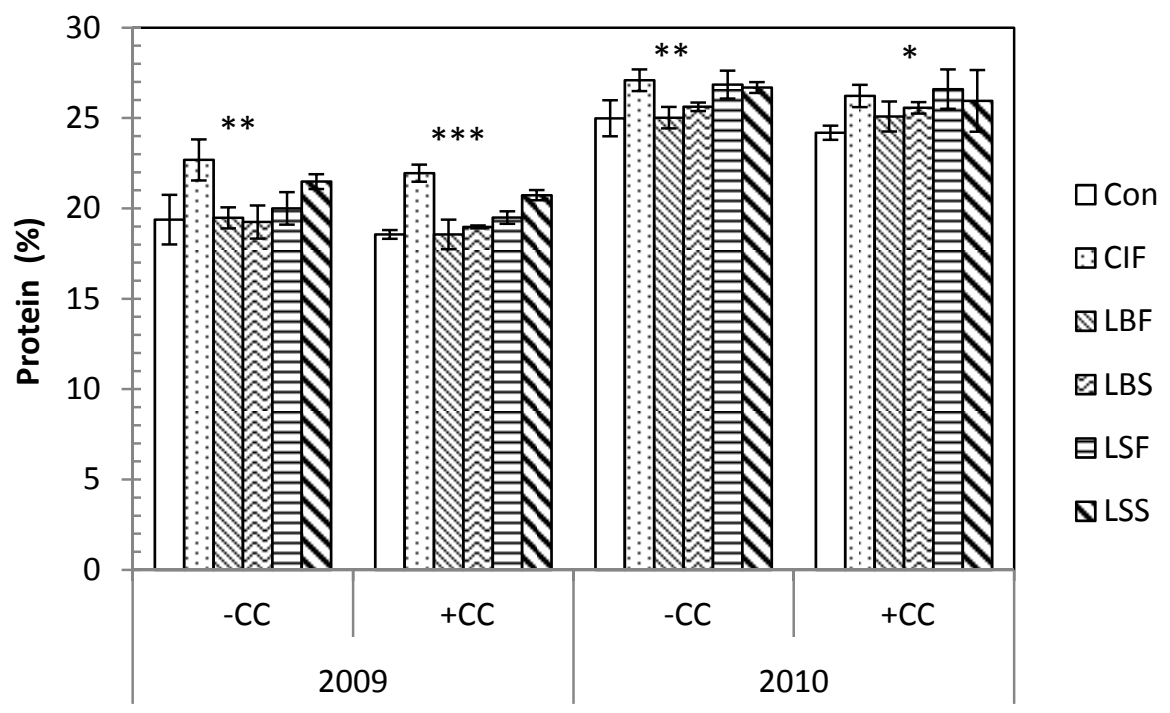

Figure 1. Content of total protein in seed harvested from cotton grown in 2009 and 2010 with $(+C C)$ or without (-CC) winter cover crop management. See Table 1 for fertilization treatment abbreviations. Data are presented as means with standard deviation bars $(\mathrm{n}=3)$. Symbols $*, * *$, and $* * *$ are for statistical significance at $P=0.05$, 0.01 , and 0.001 , respectively

Although crude protein content varied between the two years, it responded similarly to the fertilizer treatments in both years regardless of cover crop (Figure 1). The general trend of crude protein content was in the order of Con $\leq \mathrm{LBF} \leq \mathrm{LBS} \leq \mathrm{LSF} \leq \mathrm{LSS} \leq \mathrm{CIF}$. The results also reflected the properties of the two types of fertilizers - commercial inorganic fertilizer and poultry litter - and the method and timing of litter application. While $100 \%$ of the $\mathrm{N}$ supplied by the CIF treatment was plant available at the time of application in the spring, the $\mathrm{N}$ supplied by the litter becomes plant available only gradually. Additionally, the $5.6 \mathrm{Mg} / \mathrm{ha}$ litter was 
intended to supply approximately $30 \%$ less plant available $\mathrm{N}$ than the CIF so that $\mathrm{N}$ conserved by the more efficient subsurface banding method can be measured in lint yield and other measurements. Therefore, it is not surprising that the cottonseed from the CIF had the highest protein content in most cases. Interestingly, when the litter was applied by subsurface banding (LSF and LSS) in 2010, the protein content from these treatments was not different from the CIF despite the smaller amount of plant available $\mathrm{N}$ supplied by the litter. The observation that the LBF and LBS had less protein content than the CIF in both years suggests that the cotton fertilized by surface broadcast litter received less $\mathrm{N}$. But this is not surprising because substantial amount of the litter $\mathrm{N}$ is lost to volatization if applied by broadcasting on the soil surface with no incorporation into the soil. Generally, the content of crude protein of cottonseed was equal or slightly higher with PL application in Spring than in Fall, and by subsurface band than surface broadcast. We also expected that applying litter in the fall in conjunction with wheat cover crop would reduce cottonseed protein content. However, this reduction was small and statistically not significant $(P=0.05)$, indicating that much of the $\mathrm{N}$ tied up in wheat biomass was released within the cotton growing season.

It is worth pointing out that the impact of fertilization on the $\mathrm{N}$ content of the 2009 cottonseed samples was not observed in our previous report (He et al., 2013b) due to greater standard deviations (26.6-74.6\%). Those deviations were mainly due to laboratory variability. In this work, the standard deviations of these samples were much smaller (0.4-6.6\%), revealing the impacts of fertilization.

\subsection{Essential Amino acid Composition of Cottonseed}

Means and standard deviations of nine essential amino acids are presented in Figure 2. The essential amino acid arginine was eluted first from the anion chromatographic column (He et al., 2014c; Olk et al., 2008). Its peak was abnormally large (127-150 $\mathrm{g} \mathrm{kg}^{-1}$ of dry matter) and would have caused the total amino $\mathrm{N}$ content to be $42-120 \%$ greater than the $\mathrm{N}$ content of crude protein. Further control testing with cottonseed oil confirmed that the arginine peak co-eluted with the oil ingredient (data not shown), so that no data of arginine are presented in Figure 2.
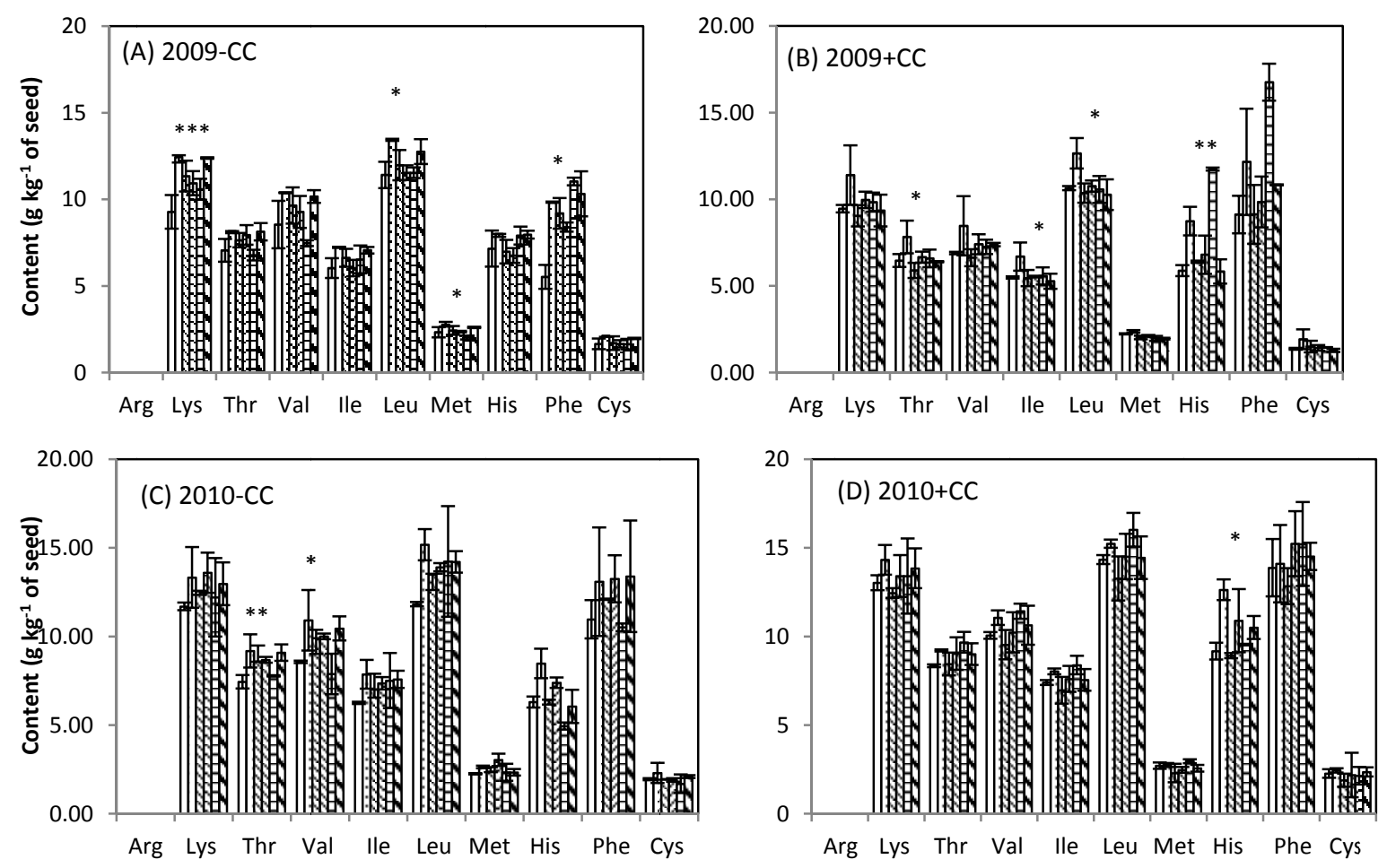

\section{$\square$ Con $\quad:$ CIF $\mathbb{N} L$ bF 圈LBS 目LSF NLSS}

Figure 2. Content of essential amino acids in seed harvested from cotton grown in 2009 and 2010 with $(+C C)$ or without (-CC) winter cover crop management. No data of arginine are available due to analytic interference. See Table 1 for fertilization treatment abbreviations. Data are presented as means with standard deviation bars ( $\mathrm{n}=2$ or 3). Symbols $*, * *$, and $* * *$ are for statistical significance at $P=0.05,0.01$, and 0.001 , respectively

The distribution of the other nine essential amino acids was similar in the four sets of samples although the 
amino acid contents of the 2009 samples were lower than their corresponding 2010 samples. Lysine, leucine, and phenylalanine were present in the greatest quantities $\left(>10 \mathrm{~g} \mathrm{~kg}^{-1}\right.$ of dry matter), and methionine and cystine were the two lowest with the quantities of $<5 \mathrm{~g} \mathrm{~kg}^{-1}$ of dry matter. These observations were consistent with previous studies of cotton seeds (Nida et al., 1996). Comparing the six fertilization treatments, statistically significant $(P \leq$ 0.05 ) changes in the essential amino acid contents were observed only for a few amino acids, and the observations were not consistent across the four sets of samples. Thus, it seemed that fertilization increased the essential amino acid contents in cottonseed compared to the control, but the current experimental data were not evident enough to distinguish the impact of the fertilization types. Previously, Bertrand et al. (2005) found no statistically significant $(P>0.05)$ difference among amino acid compositions of four conventional and genetically modified cottonseed samples.

In total, the nine essential amino acids accounted for about $32 \%$ of crude protein in these cottonseed samples. Among the six fertilization treatments the percentage varied insignificantly $(P>0.05)$ within a range of $31.2 \%$ to $32.5 \%$ of crude protein. However, the impact of the year and cover crop was statistically significant $(P<0.01)$ on the total content of the nine essential amino acids as it varied between $28.8 \%$ and $33.3 \%$ of crude protein. This observation shows a potential impact of cropping management practices on nutrient values of cottonseed. The management effect should be taken into consideration or be further evaluated for the end use where the AA composition is important, such as for animal feed (Edmunds et al., 2013) and wood adhesives (He et al., 2014a).

\subsection{Nonessential Amino Acid Composition of Cottonseed}

The contents of seven nonessential amino acids of cottonseed are present in Figure 3. The content of glutamic was around $27 \mathrm{~g} \mathrm{~kg}^{-1}$ of dry matter, the highest of all 17 amino acids measured. Aspartic was the second highest, with the quantity around $15 \mathrm{~g} \mathrm{~kg}^{-1}$ of dry matter. The other five nonessential amino acids were at a similar level of about $9 \mathrm{~g} \mathrm{~kg}^{-1}$ of dry matter. The distribution of the seven nonessential amino acids in these samples were consistent with those previously reported (Bertrand et al., 2005; Nida et al., 1996). Similar to the case of essential amino acids, fertilization management impacted the individual contents of nonessential amino acids, however, substantial standard deviations made many of these data statistically insignificant $(P>0.05)$.
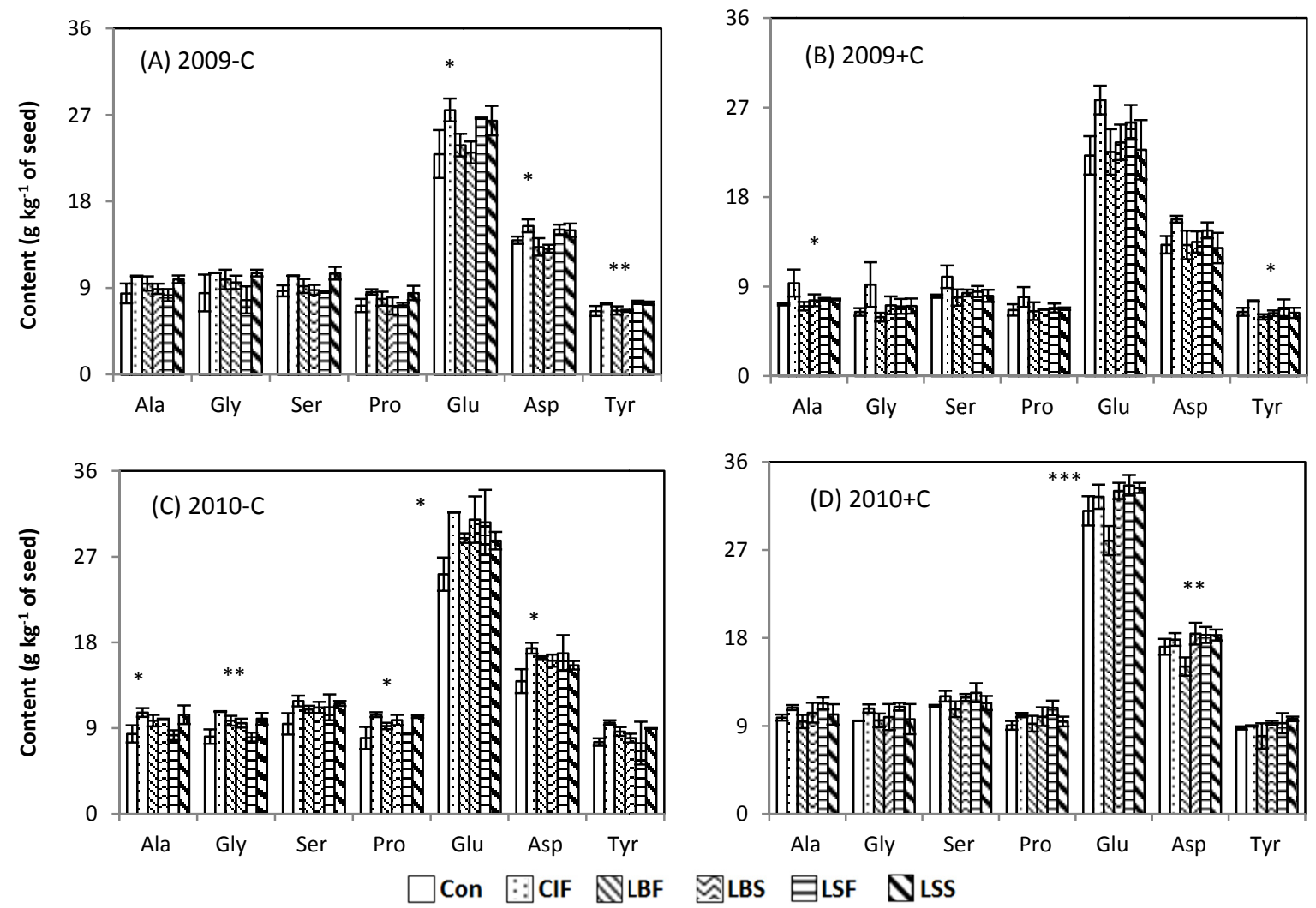

Figure 3. Content of nonessential amino acids in seed harvested from cotton grown in 2009 and 2010 with (+CC) or without (-CC) winter cover crop management. See Table 1 for fertilization treatment abbreviations. Data are presented as means with standard deviation bars $(\mathrm{n}=2$ or 3$)$. Symbols $*, * *$, and $* * *$ are for statistical significance at $P=0.05,0.01$, and 0.001 , respectively 
The total content of the seven nonessential amino acids varied within a range of $32.3 \%$ to $41.3 \%$ of crude protein with a mean of $38.3 \%$. The impact by fertilization was statistically insignificant $(P>0.05)$. However, the impacts of the year and cover crop were statistically significantly $(P<0.01)$ on the total content of the seven nonessential amino acids. Correlation analysis indicated that the levels of both essential and nonessential amino acids were highly correlated to each other, and to the crude protein (Table 2). These observations on the contents of the individual and total essential and nonessential amino acids suggested that the impact of fertilization was much more on the crude protein content than on the amino acid composition of these cottonseed samples. The total content of the seven nonessential amino acids varied within a range of $32.3 \%$ to $41.3 \%$ of crude protein with a mean of $38.3 \%$. The impact by fertilization was statistically insignificant $(P>0.05)$. However, the impacts of the year and cover crop were statistically significantly $(P<0.01)$ on the total content of the seven nonessential amino acids. Correlation analysis indicated that the levels of both essential and nonessential amino acids were highly correlated to each other, and to the crude protein (Table 2). These observations on the contents of the individual and total essential and nonessential amino acids suggested that the impact of fertilization was much more on the crude protein content than on the amino acid composition of these cottonseed samples.

Table 2. Correlation coefficients among the crude protein (CP), total essential (EAA), and nonessential (NEAA) amino acids, neutral detergent fiber (NDF) and acid detergent fiber (ADF), and acid detergent lignin (ADL) based on the two-year data $(n=24)$

\begin{tabular}{cccccc}
\hline & CP & EAA & NEAA & NDF & ADF \\
\hline EAA & $0.803^{* * *}$ & & & & \\
NEAA & $0.882^{* * *}$ & $0.964 * * *$ & & & \\
NDF & $-0.825^{* * *}$ & $-0.716^{* * *}$ & $-0.775^{* * *}$ & & \\
ADF & $-0.538^{* *}$ & $-0.546^{* *}$ & $-0.561^{* *}$ & $0.764 * * *$ & \\
ADL & $0.670^{* *}$ & $0.315 \mathrm{~ns}$ & $0.394 \mathrm{~ns}$ & $-0.351 \mathrm{~ns}$ & $0.094 \mathrm{~ns}$ \\
\hline
\end{tabular}

Symbols *,**, and *** indicate the coefficients are statistically significant at $P=0.05,0.01$, and 0.001 , respectively. Symbol "ns" indicates statistically insignificant $(P>0.05)$ coefficients.

\subsection{Total Carbon and Fiber Profiles of Cottonseed}

Carbon accounted for one half of the dry matter of cottonseed (Figure 4A). In the four sets of samples, the $\mathrm{C}$ contents varied little (ranging from 50.3\% to 51.0\%), revealing no impacts of year, cropping and fertilization management practices. These data imply that no matter how the organic compounds in cottonseed varied, the total organic carbon in the cottonseed was unchanged. This observation seemed reasonable as the majority of compounds in cottonseed are organic and mineral ash accounts for less than 5\% of dry matter (He et al., 2013b).

The content of NDF was greater in the 2009 samples than in the 2010 samples (Figure 4B), which is opposite to the trend of protein contents between the 2 years (Figure 1). In all four sets of data, the content of NDF varied with fertilization management practices, although the difference was statistically significant $(P=0.05)$ only in 2009. The impacts of fertilization type and timing were not obvious, but the NDF content seemed to be inversely related to the level of $\mathrm{N}$ nutrition. The control which received no $\mathrm{N}$ fertilization had the highest NDF while the CIF which received $\mathrm{N}$ fertilization recommended for the yield goal had the lowest NDF. Treatments that received the litter by broadcast (LBF and LBS) had less NDF than treatments that received the litter by subsurface banding (LSF and LSS) at least in 2009. On average, the contents of NDF for the cottonseed samples from the control and fertilized were $37.5 \%$ and $35.0 \%$ in 2009 and $34.8 \%$ and $33.5 \%$ in 2010 , respectively. The pattern of changes of ADF content (Figure 4C) was similar to that of NDF. Due to the lower content of ADF, no statistically significant $(P=0.05)$ difference in the ADF data was observed. On average, the contents of ADF in the control and fertilized treatments were $26.8 \%$ and $25.3 \%$ in 2009 and $25.8 \%$ and $24.8 \%$ in 2010 , respectively. The content of ADL varied from $9.0 \%$ to $10.7 \%$, but no pattern of changes was observed in the four sets of data (Figure 4D). Therefore, we conclude that the ADL content of these cottonseed samples was subject to little influence of the management practices. The levels of NDF, ADF and ADL in these cottonseed samples were similar to those in earlier National Research Council (NRC) reports (39.0, 29.0 and 10.0\%, respectively, cited from Bertrand et al., 2005), but NDF and ADF were lower than those in the cottonseed samples studied by Bertrand et al. (2005) who reported the contents of the two fibers were 52.5 and $39.1 \%$, respectively. Bertrand et al. (2005) also reported that the more statistically significant impact was observed with NDF than ADF whereas 
no data of year impact were available for ADL.

Regression analysis indicated that NDF and ADF were highly correlated to each other $(\mathrm{r}=0.764, P<0.001)$ (Table 2). Both types of fiber were negatively correlated with crude protein and amino acids at $P \leq 0.01$. This observation demonstrated that the changes of crude protein and fibers of cottonseed were in a complementary mode. The level of ADL was significantly $(P \leq 0.01)$ correlated with crude protein, however, no significant $(P>$ $0.05)$ correlations were observed between ADL with amino acids and fibers. Therefore, ADL seemed a more independent ingredient in cottonseed.
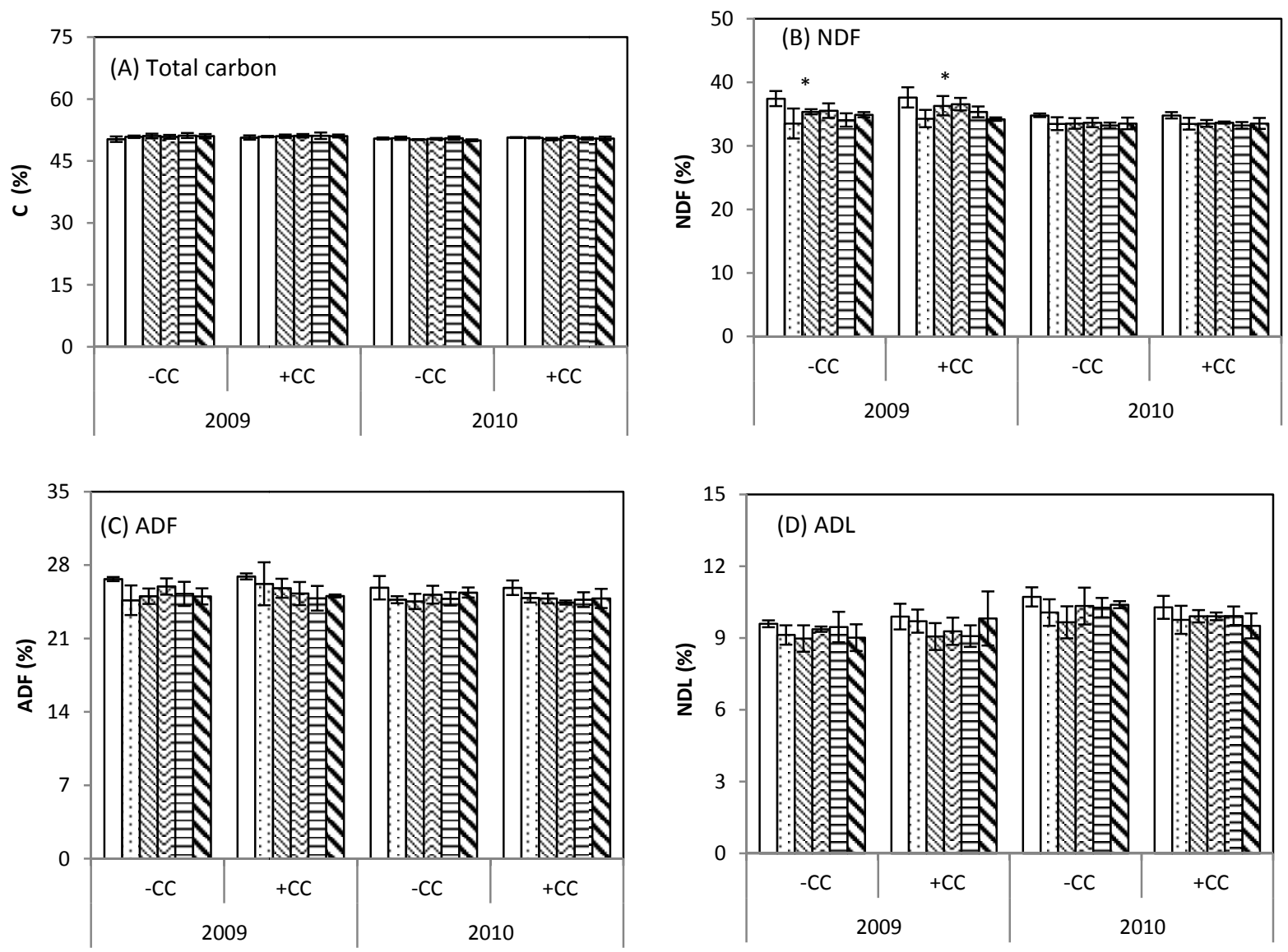

\section{$\square$ Con :: CIF $\mathbb{N}$ LBF 圈LBS 目LSF NLSS}

Figure 4. The contents of total carbon, acid detergent fiber (ADF), acid detergent lignin (ADL), and neutral detergent fiber (NDF) in seed harvested from cotton grown in 2009 and 2010 with $(+C C)$ or without (-CC) winter cover crop management. See Table 1 for fertilization treatment abbreviations. Data are presented in averages with standard deviation bars $(\mathrm{n}=3)$

\section{Conclusions}

In this study, we determined crude protein, amino acids, fibers and lignin content of cottonseed harvested from cotton grown with different fertilization managements with or without wheat cover crop in two consecutive years. Both protein and fiber profiles were consistent with previous reports. The amino acid composition and the levels of total carbon and acid detergent lignin were less affected by management practices. However, some changes of crude protein, neutral detergent and acid detergent fibers were observed among those seed samples. Generally, the cover crop management showed little impacts on the compositions of cottonseed. Fertilizer types (chemical vs. poultry litter) showed greater effects than fertilizer application method (broadcast vs. subsurface band) and time (fall vs. spring). Further statistical analysis of these data revealed that the changes of crude protein and fibers were inverse and lignin seemed a more independent ingredient in the cottonseed. Observations derived from this work will provide information on the nutritive value and digestibility of cottonseed affected by cropping management practices. 


\section{References}

ANKOM Technology. (2011). Method for determining acid detergent fiber. Retrieved from https://www.ankom.com/procedures.aspx

Bellaloui, N., \& Turley, R. B. (2013). Effects of fuzzless cottonseed phenotype on cottonseed nutrient composition in near isogenic cotton (Gossypium hirsutum L.) mutant lines under well-watered and water stress conditions. Front Plant Sci 4, 516. http://dx.doi.org/510.3389/fpls.2013.00516

Bertrand, J. A., Sudduth, T. Q., Condon, A., Jenkins, T. C., \& Calhoun, M. C. (2005). Nutrient content of whole cottonseed. J Dairy Sci, 88, 1470-1477. http://dx.doi.org/10.3168/jds.S0022-0302(05)72815-0

Coppock, C. E., Lanham, J. K., \& Horner, J. L. (1987). A review of the nutritive value and utilization of whole cottonseed, cottonseed meal and associated by-products by dairy cattle. Animal Feed Science and Technology, 18, 89-129. http://dx.doi.org/10.1016/0377-8401(87)90041-1

Edmunds, B., Sudekum, K.-H., Bennett, R., Schroder, A., Spiekers, H., \& Schwarz, F. J. (2013). The amino acid composition of rumen-undegradable protein: A comparison between forages. J Dairy Sci, 96, 4568-4577. http://dx.doi.org/10.3168/jds.2012-6536

Gao, D., Cao, Y., \& Li, H. (2010). Antioxidant activity of peptide fractions derived from cottonseed protein hydrolysate. J Sci Food Agric, 90, 1855-1860. http://dx.doi.org/10.1002/jsfa.4024

He, Z., Cao, H., Cheng, H. N., Zou, H., \& Hunt, J. F. (2013a). Effects of vigorous blending on yield and quality of protein isolates extracted from cottonseed and soy flours. Modern Appl Sci, 7(10), 79-88. http://dx.doi.org/10.5539/mas.v7n10p79

He, Z., Chapital, D. C., Cheng, H. N., \& Dowd, M. K. (2014a). Comparison of adhesive properties of water- and phosphate buffer-washed cottonseed meals with cottonseed protein isolate on maple and poplar veneers. Int $J$ Adhes Adhes, 50, 102-106. http://dx.doi.org/10.1016/j.ijadhadh.2014.01.019

He, Z., Cheng, H. N., Chapital, D. C., \& Dowd, M. K. (2014b). Sequential fractionation of cottonseed meal to improve its wood adhesive properties. $J$ Am Oil Chem Soc, 91, 151-158. http://dx.doi.org/10.1007/s11746-013-2349-2

He, Z., Olk, D. C., \& Waldrip, H. M. (2014c). Soil amino compound and carbohydrate contents influenced by organic amendments. In Z. He, \& H. Zhang (Eds.), Applied Manure and Nutrient Chemistry for Sustainable Agriculture and Environment (pp. 69-82). Springer, Amsterdam, the Netherlands, http://dx.doi.org/10.1007/978-94-017-8807-6_4

He, Z., Senwo, Z. N., Zou, H., Tazisong, I. A., \& Martens, D. A. (2014d). Amino compounds in poultry litter, litter-amended pasture soils and grass shoots. Pedosphere, 24, 178-185. http://dx.doi.org/10.1016/S1002-0160(14)60004-7.

He, Z., Shankle, M., Zhang, H., Way, T. R., Tewolde, H., \& Uchimiya, M. (2013b). Mineral composition of cottonseed is affected by fertilization management practices. Agron $J$, 105, 341-350. http://dx.doi.org/10.2134/agronj2012.0351

Kandasamy, M. M. K., Jeganathan, S., \& Ganesan, R. (2008). Operation and combustion characteristics of a direct injection diesel engine fuelled with esterified cotton seed oil. Modern Appl Sci, 2(6), 71-80. http://dx.doi.org/10.5539/mas.v2n6p71

Myer, R. O. (2012). Whole cottonseed for beef cattle rations. In AN 134 (http://edis.ifas.ufl.edu/an134, University of Florida IFAS extension). Retrieved from http://edis.ifas.ufl.edu/an134

National Forage Testing Association. (1993). Forage Analyses Procedures. Retrieved from http://www.foragetesting.org/index.php?page=lab_procedures

Nida, D. L., Patzer, S., Harvey, P., Stipoanovic, R., Wood, R., \& Fuchs, R. L. (1996). Glyphosate-tolerant cotton: the composition of the cottonseed is equivalent to that of conventional cottonseed. J Agric Food Chem, 44, 1967-1974. http://dx.doi.org/10.1021/jf950565s

Olk, D. C., Fortuna, A., \& Honeycutt, C. W. (2008). Using anion chromatography-pulsed amperometry to measure amino compounds in dairy manure-amended soils. Soil Sci Soc Am J, 72, 1711-1720. http://dx.doi.org/10.2136/sssaj2007.0420

Rasby, R., Kononoff, P. J., \& Anderson, B. E. (2008). Understanding and using a feed analysis report (University of Nebraska-Lincoln Extension. Institute of Agriculture and Natural Respources. Retrieved from 
http://www.ianrpubs.unl.edu/epublic/pages/publicationD.jsp?publicationId=1055

Yu, J., Yu, S., Fan, S., Song, M., Zhai, H., Li, X., \& Zhang, J. (2012). Mapping quantitative trait loci for cottonseed oil, protein and gossypol content in a Gossypium hirsutum x Gossypium barbadense backcross inbred line population. Euphytica, 187, 191-201. http://dx.doi.org/10.1007/s10681-012-0630-3

Zhang, B., Cui, Y., Yin, G., Li, X., \& Zhou, X. (2009). Alkaline extraction method of cottonseed protein isolate. Modern Appl Sci, 3, 77-82. http://dx.doi.org/10.5539/mas.v3n3p77

\section{Copyrights}

Copyright for this article is retained by the author(s), with first publication rights granted to the journal.

This is an open-access article distributed under the terms and conditions of the Creative Commons Attribution license (http://creativecommons.org/licenses/by/3.0/). 